\title{
Irrational Beliefs of Gifted Children's Parents in Turkey
}

\author{
Uzeyir Ogurlu (Corresponding author) \\ Graduate School of Education, Harvard University \\ 13 Appian Way, Cambridge, MA 02138, USA \\ E-mail: uzeyir_ogurlu@gse.harvard.edu
}

Suleyman Kahraman

Deparment of Psychology, Beykent University

Cumhuriyet Mah. SimSek Sok. No 1. Büyükçekmece Istanbul, 34500, Turkey

E-mail: suleymankahraman@outlook.com

Received: February 9, 2018 Accepted: March 22, 2018 Published: April 4, 2018

doi:10.5296/jei.v4i1.12633 URL: https://doi.org/10.5296/jei.v4i1.12633

\begin{abstract}
This study examined the irrational beliefs of parents of gifted children. Ninety-nine parents of gifted children in Turkey participated in the study. Parent Irrational Beliefs Scale was used as a data collection tool. Mann-Whitney's U and Kruskal-Wallis Tests were used to compare the scores. Results revealed that parents who had no training about giftedness had scored higher on parent irrational beliefs than did trained parents. In addition to training, education levels of parents had a significant effect on parent irrational beliefs. With regard to the gender of their gifted children, there were no significant differences in parent irrational beliefs scores. Parents' explanation of their difficulties with their gifted children were related to irrational beliefs.
\end{abstract}

Keywords: Gifted children, Parenting, Irrational beliefs, Parents of the gifted

\section{Introduction}

Irrational beliefs are illogical and they are incompatible with what reality says (Davies, 2006). Cognitions of parents are essential in predicting emotional reactions and parenting strategies (Bugenthal \& Johnston, 2000; McGillicuddy-DeLisi \& Siegel, 1995). Parental beliefs include child-rearing beliefs, perceptions of parental roles, self-efficacy, expectations, and attributions of their children's behaviors (Azar, Nix, \& Makin-Bryd, 2005; Bornstein \& Cote, 2004; Haskett, Scott, Grant, Ward, \& Robinson, 2003). Szentagotai and Jones (2009) summarized 
irrational beliefs identified by Ellis (1962) into four categories: demandingness (Musts, absolutes, shoulds), awfulizing (It's awful, terrible, horrible); low frustration (I can't stand it, I need it) and global evaluation of human worth (I'm, or he/she is bad, worthless). These irrational beliefs are also prevalent in parenting (Joyce, 2006). Irrational beliefs play an important role in parental perception and assessment of children's behaviors, and in attitudes towards child-rearing (Ellis, Wolfe, \& Moseley 1966; Johnston, 1996; Joyce, 1990).

Parent irrational cognitions are related to parental distress (Bugenthal \& Johnston, 2000; Joyce, 1995; McGillicuddy-DeLisi \& Siegel, 1995). Some research results have indicated that there have been positive relationships between irrational parenting beliefs and parental stress (Eryüksel \& Akün, 2003; Robin, Koepke, \& Moye, 1990; Roehling \& Robin, 1986; Starko, 1991). Also, parent irrational beliefs were linked to negative feelings of anger, depression, anxiety, and social isolation (Ackerman, 1991; Gavita, David, \& DiGiuseppe, 2014).

Similarly, irrational beliefs of parents were associated with ineffective parenting (Bernard \& Joyce 1984). Irrational beliefs of parents have also negatively influenced family atmosphere and functions (Hamamcı \& Bağc1, 2017). Studies have pointed out that training programs for parents can relieve parenting stress and irrational parental beliefs (Çekiç, Akbaş, \& Hamamc1, 2016; O. A. David, D. David, \& Dobrean, 2014; Gavita \& Joyce, 2008).

Both parent and child behaviors affect each other, but parent behaviors are also influenced by parental beliefs (Sameroff \& Fiese, 2000). The causal attributional model also works on parental beliefs on child behavior (Miller 1995). Attribution is an inference about the perceived causes of observed behaviors and events. The way individuals comprehend and manage issues in their environment is affected by attributing a cause to a specific outcome (Heider, 1958). This model explains how attributions influence emotions and behaviors in response to perceived behavior (Weiner, 1995). The approach suggests that parents have attributions and beliefs about their children's actions. Parental attributions about children's problematic behaviors were associated with parent-child interactions (Hoza, Johnston, Pillow, $\&$ Ascough, 2006). Another approach to parental beliefs is rational emotive behavioral therapy (REBT) which provides standardized assessment and intervention for parents addressing their rational and irrational beliefs (Joyce, 2006). REBT proposes that parents' irrational beliefs, including concerns about themselves, children and parenting styles, result in unhealthy negative emotions which in turn lead to negative parenting practices.

\subsection{Parents of Gifted Children}

When a family has a gifted child, parental roles change to deal with giftedness and the responsibility for parenting (Schader, 2008). Some parents felt overwhelmed when their child was identified as gifted (Rotigel, 2003). Parenting a gifted child can be relatively more stressful and challenging (Davis \& Rimm, 2004; Meckstroth, 1992; Moon \& Hall, 1998; Silverman, 1997). Parents can feel incompetent in raising a gifted child (Colangelo \& Dettman, 1983) and even sometimes cannot talk about giftedness to others (Webb \& DeVries, 1998). Delisle (2002) identified three problem areas of parenting a gifted child: rapid development of the child, inadequate knowledge about characteristics and needs of their child, and confusion about how to meet these requirements. Similarly, Clelland (2009) reported 
some cognitions and concerns of gifted children's parents, including confusion about their roles, social and emotional well-being of their children, and responsibility for needs of the children. Parents of the gifted might not have enough knowledge about developmental factors that influence their gifted children and do not know how to react to certain behaviors (Delisle, 2002; Rotigel, 2003). Parenting the gifted is related to parents' perceptions of giftedness which is based on how parents think about giftedness (Solow, 2001). Renati, Bonfiglio, and Pfeiffer (2017) found a scarcity of parenting associations, difficulties managing family routines, troubles dealing with sibling relationships, and less-than-adequate family communication as key stressors expressed by parents of the gifted. There are some biases and myths of parents which affect their parenting practices as well (Shore, Cornell, Robinson, \& Ward, 1991; Welsh, 2014). Examples of these myths are the idea that gifted children can be successful in all areas, have more problematic behaviors, need more discipline, and develop as well physically and emotionally as they do intellectually.

Parents of the gifted have various needs in parenting. Researchers have an agreement about some needs including perceptions and expectations about giftedness, parenting, educational support, and social-emotional development of their children (Colangelo \& Davis, 2003; Silverman \& Golon, 2008; Silverman, 2013). Karakuş (2010) studied the difficulties of parents of the gifted in Turkey and found that main challenges of parents of the gifted were dealing with their children's questions, unique characteristics, and their communication issues with their children, and educational concerns. Ogurlu and Yaman (2013) examined counseling needs of parents of gifted students. Parents reported the most needs as oversensitivity and perfectionism of gifted children and lack of educational programs for them.

\subsection{The Current Study}

Many researchers have agreed that examining parents' beliefs system was crucial for understanding parenting behaviors (Goodnow, 1995; McGillicudy-DeLisi \& Sigel, 1995). Gifted children were likely to be more sensitive to family environment factors than non-gifted peers (Abelman, 1991; Dwairy, 2004). In other words, familial factors might have a higher effect on gifted students. According to May (1994), parent-child interaction is one of the most significant factors in the development of gifted children. Therefore, studies should be conducted to examine parents' beliefs, perceptions, and attitudes to understand better parenting approaches and practices in parenting the gifted. Also, Coon (2004) emphasized the importance of interaction between students, teachers, and parents in gifted education. In addition, investigation of irrational parent beliefs can help identify the needs of parents of gifted children in the process of education of their children. After they had reviewed 53 studies about parents of the gifted, Jolly and Matthews (2012) stated that more research was needed to better understand the parents of gifted children. Likewise, some researchers stressed the lack of research about the parenting in the field of gifted education (Morawska \& Sanders, 2009; Reichenberg \& Landau, 2009). This study can provide an understanding how some variables would affect irrational beliefs of families of the gifted. Given the importance of parental perceptions and beliefs about the parenting to their children and the potential influence of these beliefs on the well-being of gifted children, the aim of the present study 
was to scrutinize factors associated with irrational parental beliefs of gifted students' parents. The findings of the current study might provide initial insights into the development of training programs for parents of gifted children. This study aimed to answer the following questions:

(1) Are there any differences in the parents' irrational beliefs scores regarding getting training, education levels of parents, the first awareness of giftedness, and genders of their gifted children?

(2) Are there any differences in the parent's irrational beliefs regarding difficulty explanations patterns of parents about their children?

\section{Method}

\subsection{Participants}

A sample of participants $(n=99)$ was initially recruited through the online application for a project for gifted students in Turkey. Parents who wanted their gifted children to participate in the project were asked to complete the survey that included demographic information and a scale which is explained in the data collection. The participants of the study were composed of 99 parents who filled out the survey. The requirement for the application was to have a gifted child who was attending Science and Art Centers (SAC), a state-funded institution providing the special education for primary and secondary school gifted students apart from their usual school time. In other words, to be included in the study, parents had at least one gifted child in their family. For admission to SAC, students are first nominated by teachers using specific observation forms and then, all nominated students take a simultaneous group test. A certain number of students who are ranked according to the test scores are taken based on an individual intelligence test. Finally, the students whose total intelligence test score is above 130 get the acceptance to SAC within the numbers allotted each year for the centers. Those who become part of the SAC program continue to attend their regular schools as well. These centers function as enrichment and grouping models in which selected gifted students participate after their school day (Sak, 2010). According to Ministry of National Education (2017), there were 24291 gifted students attending 106 Science and Art Centers in Turkey in the school year 2015-16.

The project was for gifted children in middle school, grades 5 through 8 . Ninety-nine parents in the study had 33 gifted female and 65 gifted male students. Of those students in the study, 34 were attending public schools and 64 students were attending private schools. The participants included 75 mothers and 24 fathers whose education levels were high school and beyond.

\subsection{Data Collection Instruments}

Parents who chose to participate in the study were presented with a questionnaire on the project website including socio-demographic information and the Parent Irrational Beliefs Scale, explained in the following:

Parent Irrational Beliefs Scale (PIBS): Kaya and Hamamcı (2013) developed the scale to 
examine parents' irrational beliefs. The scale has 29 items with 5-point Likert-type and two subscales; expectations sub-scale which includes parental irrational expectations from their children, and perfectionism sub-scale which contains items regarding parents' perfectionist views about parenting. The higher scores of the scale show higher levels of irrational beliefs about parenting. Confirmatory Factor Analysis showed good fit indices for the data obtained from parents with secondary school children. The test-retest correlations were .81 for Expectations sub-scale and .71 for Perfectionism sub-scale. Internal consistency coefficients were .85 for Expectations and .82 for Perfectionism. In this study, Cronbach's Alpha was found as .90 for expectation subscale and .89 for perfectionism subscale and .92 for a total score.

\subsection{Data Collection and Analysis}

The project was accepted by The Scientific and Technological Research Council of Turkey (TUBITAK), the Turkish agency for management, funding, and conduct of research. All official permissions were approved by this agency for gathering the data. On the project website, there was information about the importance, goals, target groups and dates of the study. Parents who were interested in participating in the study visited the application page, which contained a link to the online survey, and then followed this online link to the consent document and then progressed to the survey measures. The survey could be completed in 10-15 minutes.

It is essential to ensure that data indicates the normal distribution to use parametric tests in data analysis. Therefore, The Shapiro-Wilk test of normality was used to examine the normal distribution of the score because it was more appropriate for the small sample size. The p-value for the Shapiro-Wilk test is 0.026 , suggesting that the data was not normally distributed. Nonparametric (e.g., Mann-Whitney's U, Kruskal-Wallis Test) independent samples tests were used to compare the scores because scores of parental irrational beliefs scale were not normally distributed. The effect sizes were computed by the Cohen's d.

In addition to the scale, we asked parents great difficulties they had with their gifted children as an open-ended question, to examine whether parental irrational beliefs differ regarding parents' attributions of the difficulty with their children. The responses to the open-ended question were analyzed by using inductive content analysis in which coding categories are derived inductively from their responses. Both authors carefully examined the responses about parents' difficulties with their children to find themes and categories that emerge from the data. Each parent stated the biggest difficulty that they had while living with their children, and that statement about the problems was accepted as the unit for analysis. In coding the responses, researchers found three attributions that the parents often addressed in their responses. To identify patterns of explanations that parents used to state their attributions of difficulties, we divided their statements into three categories according to their attributions; difficulties that are attributed to insufficiency of educational environment for gifted students (Education-directed difficulties); are ascribed to characteristics of gifted children (Gifted children-directed difficulties), and attributed to parents own efficacy (Parents-directed difficulties). Table 1 shows examples of responses under each category. 


\section{Macrothink}

Table 1. Categories of difficulties as stated by parents of gifted children

\begin{tabular}{|c|c|}
\hline Categories & Examples of responses \\
\hline \multirow[t]{7}{*}{ Education-directed difficulties } & $\begin{array}{l}\text { Misrepresentations and stigmatization of these children by school } \\
\text { administrators and teachers }\end{array}$ \\
\hline & There is no school in my city to improve my child's interests and skills \\
\hline & There are not enough trained instructors to educate them \\
\hline & $\begin{array}{l}\text { Not receiving sufficient education. At the same time, they ignore their } \\
\text { emotional needs. }\end{array}$ \\
\hline & One of the biggest problems we have is with teachers at the school \\
\hline & Unfortunately, our country cannot educate these children properly \\
\hline & He gets bored in classes because he understands things quickly \\
\hline \multirow[t]{6}{*}{ Gifted children-directed difficulties } & Getting stuck in details by asking too many questions \\
\hline & Intolerance \\
\hline & $\begin{array}{l}\text { Excessive self-esteem, and therefore underestimating many things, } \\
\text { always objecting and questioning }\end{array}$ \\
\hline & Having a stubborn personality \\
\hline & Being untidy \\
\hline & Too much detail \\
\hline \multirow[t]{8}{*}{ Parent-directed difficulties } & I do not understand my daughter in some cases \\
\hline & I cannot meet his interests \\
\hline & I have communication problems with my kid \\
\hline & My expectations are too high \\
\hline & Not being able to give enough answers to her questions \\
\hline & I cannot help him enjoy life \\
\hline & Cannot satisfy his curiosity \\
\hline & $\begin{array}{l}\text { I do not have enough knowledge about how to understand or } \\
\text { communicate with her correctly }\end{array}$ \\
\hline
\end{tabular}

The authors independently coded sentences for the categories and then we calculated kappa as a measure of interrater agreement that revealed a high level of agreement among the codes (.86). Disagreements were resolved by reexamining the statements and reaching consensus. Parents stated 32 education-directed difficulties, 25 gifted children- directed difficulties and 24 parent-directed difficulties.

\section{Results}

We asked parents whether or not they got any training about giftedness and classified them into two groups, trained parents and untrained parents, based on their responses. A 
Mann-Whitney U Test was conducted to determine whether there was a difference between trained and non-trained parents in the parental irrational beliefs. The results are shown in Table 2.

Table 2. Results of Mann-Whitney U Test for parent irrational beliefs scale by getting trained

\begin{tabular}{|c|c|c|c|c|c|c|c|}
\hline PIBS & Training & $\mathrm{N}$ & Mean Rank & Sum of Ranks & $U$ & $Z$ & $p$ \\
\hline \multirow[t]{2}{*}{ Expectations } & Trained & 35 & 43.66 & 1528.0 & \multirow{2}{*}{898.00} & \multirow{2}{*}{-1.62} & \multirow{2}{*}{.104} \\
\hline & Non-trained & 64 & 53.47 & 3422.0 & & & \\
\hline \multirow[t]{2}{*}{ Perfectionism } & Trained & 35 & 42.66 & 1493.0 & \multirow{2}{*}{863.00} & \multirow{2}{*}{-1.88} & \multirow{2}{*}{.060} \\
\hline & Non-trained & 64 & 54.02 & 3457.0 & & & \\
\hline \multirow[t]{2}{*}{ Total } & Trained & 35 & 40.73 & 1425.5 & \multirow{2}{*}{795.50} & \multirow{2}{*}{-2.37} & \multirow{2}{*}{.018} \\
\hline & Non-trained & 64 & 55.04 & 3524.5 & & & \\
\hline
\end{tabular}

Results of the analysis indicated that non-trained parents (mean rank $=55.04$ ) scored higher on the total score of parent irrational beliefs than trained parents (mean rank $=40.73$ ). Mann-Whitney $U$ value was found to be statistically significant $U=755.50(Z=-2.37), p<$ 0.05 , and the effect size was $(d=.49)$ which was medium effect size (Cohen, 1988). Even though trained parents had lower scores in perfectionism and expectation subscales than non-trained parents, these differences were not statistically significant. In addition to training, education levels of parents were examined in terms of irrational parental beliefs. The participants had educational levels of high school and beyond. Scores of parents who had high school degree were compared to the score of parents who had college or post-college degrees. The results were given in Table 3 .

Table 3. Results of Mann-Whitney U Test for parent irrational beliefs scale by education level

\begin{tabular}{|l|l|l|l|l|l|l|l|}
\hline PIBS & Education Level & $\mathrm{N}$ & Mean Rank & Sum of Ranks & $U$ & $Z$ & $p$ \\
\hline \multirow{3}{*}{ Expectations } & High School & 55 & 55.29 & 3041.0 & \multirow{2}{*}{919.00} & -2.05 & \multirow{2}{*}{.04} \\
\cline { 2 - 9 } & College or More & 44 & 43.39 & 1909.0 & & & \\
\hline \multirow{2}{*}{ Perfectionism } & High School & 55 & 55.93 & 3076.0 & \multirow{2}{*}{884.00} & -2.29 & .02 \\
\cline { 2 - 9 } & College or More & 44 & 42.59 & 1874.0 & & & \\
\hline \multirow{2}{*}{ Total } & High School & 55 & 57.27 & 3150.0 & \multirow{2}{*}{810.00} & -2.81 & .00 \\
\cline { 2 - 9 } & College or More & 44 & 40.91 & 1800.0 & & & \\
\hline
\end{tabular}

As seen in Table 3, parents whose education levels were high school degree (mean rank = 57.27) had a higher total score of parent irrational beliefs than parents who had college or post-college degree (mean rank $=40.91$ ). Mann-Whitney U value was statistically significant 


\section{MInstitute Macrothink}

$U=810.00(Z=-2.81), p<0.01$, and the effect size was medium $(d=.59)$. In addition to total score, there were statistically differences in expectations $(U=919.00, Z=-2.05, p<.05$, $d=.42)$ and perfectionism $(U=884.00, Z=-2.29, p<.05, \mathrm{~d}=.47)$ subscales in terms of education levels of parents. After education levels of parents, Mann-Whitney $U$ was conducted to compare parent irrational beliefs between parents who had a gifted male and who had a gifted female. In other words, the effect of genders of gifted children on parent irrational beliefs was examined, and the results were given in Table 4.

Table 4. Results of Mann-Whitney U Test for parent irrational beliefs scale by gender of gifted children

\begin{tabular}{|l|l|l|l|l|l|l|l|}
\hline PIBS & Gender & $\mathrm{N}$ & Mean Rank & Sum of Ranks & $U$ & $Z$ & $p$ \\
\hline \multirow{2}{*}{ Expectations } & Female & 34 & 51.71 & 1758.00 & \multirow{2}{*}{1047.00} & \multirow{2}{*}{-.428} & \multirow{2}{*}{.66} \\
\cline { 2 - 8 } & Male & 65 & 49.11 & 3192.00 & & & \\
\hline \multirow{2}{*}{ Perfectionism } & Female & 34 & 49.99 & 1699.50 & \multirow{2}{*}{1104.50} & -.004 & .99 \\
\cline { 2 - 9 } & Male & 65 & 50.01 & 3250.50 & & & \\
\hline \multirow{2}{*}{ Total } & Female & 34 & 50.34 & 1711.50 & \multirow{2}{*}{1093.50} & -.085 & .93 \\
\cline { 2 - 5 } & Male & 65 & 49.82 & 3238.50 & & & \\
\hline
\end{tabular}

According to Table 4, there was no significant difference in parent irrational beliefs scores regarding genders of their gifted children $(U=1093.50, Z=-.085, p>.05)$. Namely, the gender of gifted children didn't seem to have an effect on parent irrational beliefs in the study.

Referral for identification or nomination to gifted programs is the first entry point for identification of a child as gifted. In some cases, parents might notice the special characteristics of their own children, but in other cases teachers or others do. We analyzed irrational parent beliefs by who first realized the giftedness of children. According to Table 5, teachers (63) noticed the giftedness much more than parents (12) in the study. Others included aunts, uncles, doctors, psychologists, or other people other than parents and teachers. 


\section{Macrothink}

Table 5. Results of Kruskal-Wallis Test for parent irrational beliefs scale by referral

\begin{tabular}{|c|c|c|c|c|c|c|}
\hline PIBS & Who First Noticed & $\mathrm{N}$ & Mean Rank & $X^{2}$ & $d f$ & $p$ \\
\hline \multirow[t]{3}{*}{ Expectations } & Parents & 24 & 50.94 & \multirow{3}{*}{1.497} & \multirow{3}{*}{2} & \multirow{3}{*}{.47} \\
\hline & Teachers & 63 & 47.95 & & & \\
\hline & Others & 12 & 58.88 & & & \\
\hline \multirow[t]{3}{*}{ Perfectionism } & Parents & 24 & 58.58 & \multirow{3}{*}{3.673} & \multirow{3}{*}{2} & \multirow{3}{*}{.15} \\
\hline & Teachers & 63 & 48.58 & & & \\
\hline & Others & 12 & 40.29 & & & \\
\hline \multirow[t]{3}{*}{ Total } & Parents & 24 & 56.44 & \multirow{3}{*}{1.612} & \multirow{3}{*}{2} & \multirow{3}{*}{.44} \\
\hline & Teachers & 63 & 47.74 & & & \\
\hline & Others & 12 & 49.00 & & & \\
\hline
\end{tabular}

A Kruskal-Wallis Test was conducted to evaluate differences in groups who first noticed the giftedness of children on the median change in parent irrational beliefs (Table 5). Results of that analysis showed that there was no significant difference between groups in irrational parental beliefs $\left(\chi^{2}(2)=1.61, p=.44\right)$.

We categorized how parents attributed the biggest difficulties with their children into education-directed, gifted children-directed, parents-directed difficulties. Education- directed challenges referred to difficulties that parents stated about educational issues like school, programs or teachers' attitudes. Children-directed challenges that parents mentioned included concerns about the characteristics of gifted children such as asking too many questions or their personality. Parent-directed difficulties meant that parents saw themselves as the reasons for difficulties such as feeling insufficient, having high expectations or not knowing how to behave. The most stated problem by parents was educational difficulties about their gifted children. A Kruskal-Wallis Test was run to compare parent irrational beliefs between three difficulty explanations. The results were presented in Table 6 . 
Table 6. Results of Kruskal-Wallis Test for parent irrational beliefs scale by difficulties

\begin{tabular}{|c|c|c|c|c|c|c|}
\hline PIBS & Difficulties & $\mathrm{N}$ & Mean Rank & $X^{2}$ & $d f$ & $p$ \\
\hline \multirow[t]{3}{*}{ Expectations } & Education-Directed & 32 & 35.77 & \multirow{3}{*}{5.914} & \multirow{3}{*}{2} & \multirow{3}{*}{.05} \\
\hline & Gifted Children-Directed & 25 & 38.46 & & & \\
\hline & Parents-Directed & 24 & 50.63 & & & \\
\hline \multirow[t]{3}{*}{ Perfectionism } & Education-Directed & 32 & 32.95 & \multirow{3}{*}{13.871} & \multirow{3}{*}{2} & \multirow{3}{*}{.00} \\
\hline & Gifted Children-Directed & 25 & 37.14 & & & \\
\hline & Parents-Directed & 24 & 55.75 & & & \\
\hline \multirow[t]{3}{*}{ Total } & Education-Directed & 32 & 33.41 & \multirow{3}{*}{11.512} & \multirow{3}{*}{2} & \multirow{3}{*}{.00} \\
\hline & Gifted Children-Directed & 25 & 37.90 & & & \\
\hline & Parents-Directed & 24 & 54.35 & & & \\
\hline
\end{tabular}

Kruskal-Wallis Test indicated that there was a statistically significant difference between difficulty explanations on the total score of parents' irrational beliefs $\left(\chi^{2}(2)=13.87, p=.00\right)$. Also, the medians of subscales were not equal. Follow-up tests were conducted to evaluate pairwise differences among the three groups, controlling for Type I error across tests by using the Bonferroni approach. The results of Mann-Whitney $U$ Tests indicated a significant difference between total median of parent-directed difficulties and median of gifted children-directed difficulties $(U=178.50, Z=-2.43, p<.05, \mathrm{~d}=.74)$ and between total median of parent-directed difficulties and median of education directed difficulties $(U=$ 185.00, $Z=-3.29, p<.01, d=.69$ ). In other words, parents who presented parent-directed difficulties had higher levels of parent irrational beliefs than both who stated education-directed difficulties and who said gifted children-directed difficulties.

\section{Discussion}

The aim of the current study was to examine some factors associated with irrational parental beliefs of gifted students' parents. Results of the study provided some insights into whether there were differences in the parents' irrational beliefs regarding getting trained, education level of parents, first awareness of giftedness, genders of their gifted children, and difficulty explanation patterns of parents about the parental irrational beliefs score.

The study concluded that non-trained parents of gifted students scored higher on parent irrational beliefs than did trained parents. This result might be expected because parents generally have developed child-rearing behaviors and attitudes according to the average child (Ross, 1964). When the child does not meet the regular expectation, parents might have trouble dealing with the child. Many researchers emphasized that parenting the gifted could be relatively more stressful and parents needed guidance and support for parenting (Colangelo \& Dettmann, 1983; Clelland, 2009; Davis \& Rimm, 2004; Huff, Houskamp, Watkins, Stanton, \& Tavegia, 2005; Meckstroth, 1992; Moon \& Hall, 1998; Pfeiffer, 2013; Rotigel, 2003; Silverman, 2013). Moreoever, some research showed that the training helps 
parents alleviate their anxieties about their children and rear their children (Kahraman, 2016; Morawska, \& Sanders, 2008; Ogurlu, 2016; Weber \& Stanley, 2012). Even though we did not know the quality of the training that parents had, the training did have an effect on irrational parental beliefs in the study. Based on the result, it is plausible to assume that lack of information about giftedness can make the parents get confused about their roles and parenting to their gifted children.

Similar to the training effect, parents whose education levels were high school had a higher total score of parent irrational beliefs than parents who had college and post-college degree. The parental educational level is an essential predictor of the quality of family interactions and child behavior (Davis-Kean, 2005; Dubow, Boxer, \& Huesmann, 2009). It can be speculated that formal education might provide self-confidence and personal efficacy to the parents about parenting. Attending higher levels of schooling might offer more access to resources that allow for more effective parental strategies and also enable parents to acquire more effective problem-solving strategies and social skills that help them deal with their gifted children. Although there are differences regarding parent expectations and confidence in their ability to manage and assist their gifted child, parents with higher education are more confident (Chan, 2005; Dwairy, 2004; Huff et al., 2005; Morawska \& Sanders, 2008; Winner, 2000). Parents who have higher education might have more awareness of parenting. Having more awareness might be a considerable factor in having less irrational beliefs.

In the study, genders of gifted children had no significant effect on parent irrational beliefs scores. This result might show that parents did not have gender biased beliefs or attitudes toward their children. Their irrational parental beliefs did not change based on the gender of their children. Another notable result of the study was that teachers had noticed the giftedness much more than parents. It is plausible to mention that teachers have more opportunities, knowledge, and experience in understanding giftedness. Also, giftedness symptoms can be manifested in class activities more easily than in typical life situations. This opportunity might give teachers more chance to see gifted performances than parents. However, parent irrational beliefs did not differ in terms of whoever first realized the giftedness in children.

Although the present study found a high prevalence of educational difficulties of gifted children stated by parents, those who attributed the problems to their own insufficiency about parenting had higher levels of parent irrational beliefs. Some parents of gifted children might feel inadequacy for parenting their gifted child (Delisle, 2002; Freeman, 1995). Thus, this feeling and lack of information about giftedness may leave the parents confused about their parenting roles thereby letting them have some irrational thoughts. Attributions and explanations might influence how individuals behave (Weiner, 1995).

The main implication of the study was the importance of training parents about giftedness. Needless to say, training programs should be developed about effective parenting. Before offering training for parents, experts and practitioners need training about giftedness because many experts in family dynamics do not have sufficient competence and experience in giftedness (Moon \& Thomas, 2002). Teachers also should be trained in ways they can effectively teach because the parents in the study were concerned about their children's 
education. Parenting a gifted child can be a challenge when parents have high irrational beliefs.

\subsection{Limitations and Recommendations}

The study has some limitations. Participants in the research included a small sample of parents, with limited differences in diversity and socioeconomic levels. Parents from diverse populations should be included for further studies. Socio-demographic information such as family dynamics, having a twice-exceptional child, personality types of parents can be useful in understanding the phenomena.

Another limitation was the collection of data through self-report. Self-ratings can be biased mainly if participants want to indicate themselves in a positive condition. The inclusion of multiple forms of data, such as observation and interview can reduce this potential bias. Gifted children of parents in the study had attended a special program for gifted students. Therefore, parents of other gifted students who do not get any special support should be involved in further research. The attributions of explanations that parents express about the difficulties of their children were analyzed and categorized by using only one statement of parents. Thus, attribution of gifted children's parents should be examined in more detail in future research. It may be worthwhile to further research the effect of parents' irrational beliefs on some psychological concerns of gifted students, such as depression, anxiety, or academic achievement. Also, the irrational beliefs of gifted students about their parents, teachers, friends or themselves and the factors that affect their irrational beliefs should be investigated to gain a better understanding of their social and emotional life.

\section{References}

Ackerman, K. A. (1991). Irrational Beliefs and Parenting Stress (Unpublished Doctoral Dissertation, University of Alberta, Canada).

Azar, S. T., Nix, R. L., \& Makin-Bryd, K. N. (2005). Parenting schemas and process of change. Journal of Marital and Family Therapy, 31, 45-48. https://doi.org/10.1111/ j.1752-0606.2005.tb01542.x

Bernard, M. E., \& Joyce, M. R. (1984). Rational Emotive Therapy with children and adolescents: Theory, treatment strategies, preventive methods. New York: Wiley and Sons.

Bornstein, H. M., \& Cote, L. R. (2004). Mothers' parenting cognitions in cultures of origin, acculturating cultures, and cultures of destination. Child Development, 75, 221-235. https://doi.org/10.1111/j.1467-8624.2004.00665.x

Bugental, D. B., \& Johnston, C. (2000). Parental and child cognitions in the context of the family. Annual Review of Psychology, 51, 315-344. https://doi.org/10.1146/annurev.psych. 51.1.315

Çekiç, A., Akbaş, T., \& Hamamc1, Z. (2016). The effect of rational emotive parent education program on parents' irrational beliefs and parenting stress. International Journal of Human Sciences, 13(1), 2398-2417. https://doi.org/10.14687/ijhs.v13i1.3729 
Chan, D. W. (2005). Family environment and talent development of Chinese gifted students in Hong Kong. Gifted Child Quarterly, 49(3), 211-221. https://doi.org/10.1177/00169862 0504900303

Clelland, D. A. (2009). Needs for information and concerns of parents of gifted children in four Canadian provinces (Unpublished Doctoral Dissertation, Faculty of Education-Simon Fraser University).

Cohen, J. (1988). Statistical power analysis for the behavioral sciences (2nd ed.). Hillsdale, NJ: Lawrence Earlbaum Associates.

Colangelo, N., \& Davids, G. (2003). Handbook of Gifted Education. Pearson Education, Inc., Boston.

Colangelo, N., \& Dettman, D. (1983). A review of research on parents and families of gifted children. Exceptional Education, 50, 20-27. https://doi.org/10.1177/001440298305000103

Coon, P. (2004). Trigram: A gifted program model all students can enjoy. Rural Special Education Quarterly, 23(1), 22-25. https://doi.org/10.1177/875687050402300105

David, O. A., David, D., \& Dobrean, A. (2014). Efficacy of the rational positive parenting program for child externalizing behavior: Can an emotion-regulation enhanced cognitive-behavioral parent program be more effective than a standard one? Journal of Evidence-Based Psychotherapies, 14(2), 159-178.

Davies, M. F. (2006). Irrational beliefs and unconditional self-acceptance. I. Correlational evidence linking two key features of REBT. Journal of Rational-Emotive and Cognitive-Behavior Therapy, 24(2), 113-124. https://doi.org/10.1007/s10942-006-0027-0

Davis, G. A., \& Rimm S. B. (2004). Education of the gifted and talented. Pearson/A and B.

Davis-Kean, P. E. (2005). The influence of parent education and family income on child achievement: The indirect role of parental expectations and the home environment. Journal of Family Psychology, 19(2), 294. https://doi.org/10.1037/0893-3200.19.2.294

Delisle, J. R. (2002). Barefoot irreverence: A collection of writings on gifted child education. Prufrock Press Inc.

Dubow, E. F., Boxer, P., \& Huesmann, L. R. (2009). Long-term effects of parents' education on children's educational and occupational success: Mediation by family interactions, child aggression, and teenage aspirations. Merrill-Palmer Quarterly, 55(3), 224-236 https://doi.org/ $10.1353 / \mathrm{mpq} .0 .0030$

Dwairy, M. (2004). Parenting styles and mental health of Arab gifted adolescents. Gifted Child Quarterly, 48, 275-286. https://doi.org/10.1177/001698620404800403

Ellis, A. (1962). Reason and emotion in psychotherapy. New York: Lyle Stuart.

Ellis, A., Wolfe, J., \& Moseley, S. (1966). How to raise an emotionally healthy, happy child. New York: Crown. 
Eryüksel, A., \& Akün, E. (2003). Depresyonu olan ergenler ile anne babalarının aile ilişkilerinin ve bilişsel çarpıtmalarının incelenmesi. Türk Psikoloji Dergisi, 18, 59-79.

Freeman, J. (1995). Annotation: Recent studies of giftedness in children. The Journal of Child Psychology and Psychiatry and Allied Disciplines, 36(4), 531-547. https://doi.org/ 10.1111/j.1469-7610.1995.tb02313.x

Gavita, O. A., \& Joyce, M. (2008). A review of the effectiveness of cognitively enhanced behavioral based group parent programs designed for reducing disruptive behavior in children. Journal of Cognitive and Behavioral Psychotherapies, 8, 185-199.

Gavita, O. A., David, D., \& DiGiuseppe, R. (2014). You are such a bad child! Appraisals as mechanisms of parental negative and positive affect. The Journal of General Psychology, 141(2), 113-129. https://doi.org/10.1080/00221309.2013.874971

Goodnow, J. J. (1995). Parents' knowledge and expectations. In M. H. Bornstein (Ed.), Handbook of parenting (Vol. 3, pp. 305-332). Mahwah, NJ: Erlbaum

Hamamc1, Z., \& Bağc1, C. (2017). Analyzing the relationship between parent's irrational beliefs and their children's behavioral problems and family function. Gaziantep University Journal of Social Sciences, 16 (3), 733-740. https://doi.org/10.21547/jss.292722

Haskett, M. E., Scott, S., Grant, R., Ward, C. S., \& Robinson, C. (2003). Child related cognition and affective functioning of physically abusive and comparison parents. Child Abuse and Neglect, 27, 663-686. https://doi.org/10.1016/S0145-2134(03)00103-0

Heider, F. (1958). The psychology of interpersonal relations. New York: Wiley. https://doi.org/10.1037/10628-000

Hoza, B., Johnston, C., Pillow, D. R., \& Ascough, J. C. (2006). Predicting treatment response for childhood attention-deficit/hyperactivity disorder: Introduction of a heuristic model to guide research. Applied and Preventive Psychology, 11, 215-229. https://doi.org/10.1016/ j.appsy.2005.11.001

Huff, R. E., Houskamp, B. M., Watkins, A. V., Stanton, M., \& Tavegia, B. (2005). The experiences of parents of gifted African American children: A phenomenological study. Roeper Review, 27(4), 215-221. https://doi.org/10.1080/02783190509554321

Johnston, C. (1996). Addressing parent cognitions in interventions with families of disruptive children. In K. S. Dobson \& K. D. Craig (Eds.), Banff international behavioral science series. Advances in cognitive-behavioral therapy (Vol. 2, pp. 193-209). Thousand Oaks, CA: Sage Publications.

Jolly, J. L., \& Matthews, M. S. (2012). A critique of the literature on parenting gifted learners. Journal for the Education of the Gifted, 35(3), 259-290. https://doi.org/10.1177/0162353212 451703

Joyce, M. R. (1990). Rational-emotive parent consultation. School Psychology Review, 19, 808-314. 
Joyce, M. R. (1995). Emotional relief for parents: Is rational-emotive parent education effective? Journal of Rational-Emotive and Cognitive-Behavior Therapy, 13, 55-76. https://doi.org/10.1007/BF02354557

Joyce, M. R. (2006). A developmental, rational emotive behavioral approach for working with parents. In A. Ellis \& M. E. Bernard (Eds.), Rational-emotive treatment of childhood problems (pp. 177-212). Springer, Boston, MA. https://doi.org/10.1007/0-387-26375-6_6

Kahraman, S. (2016). Ebeveynin üstün yetenekli çocuğuyla iletişimini geliştirmeye yönelik psikoeğitim programının etkisinin incelenmesi (Unpublished Doctoral Thesis, Fatih University, İstanbul).

Karakuş, F. (2010). Üstün yetenekli çocukların anne babalarının karşılaştıkları güçlükler. Mersin Üniversitesi Eğitim Fakültesi Dergisi, 6(1), 127-144.

Kaya, İ., \& Hamamc1, Z. (2011). Development of the Parent Irrational Beliefs Scale. Educational Sciences: Theory \& Practice, 11(3), 1149-1165.

May, K. M. (1994). A developmental view of a gifted child's social and emotional adjustment. Roeper Review, 17, 105-109. https://doi.org/10.1080/02783199409553635

McGillicuddy-De Lisi, A. V., \& Sigel, I. E. (1995). Parenting Beliefs are Cognitions: The Dynamic Belief Systems Model. In M. H. Bornstein (Ed.), Handbook of parenting (Vol. 3, pp. 333-358). Hillsdale, NJ: Lawrence Erlbaum Associates.

Meckstroth, E. (1992). Family issues: Paradigm shifts into giftedness. Roeper Review, 15(2), 91-92. https://doi.org/10.1080/02783199209553472

Miller, S. A. (1995). Parents' attributions for their children's behavior. Child Development, 66, 1557-1584. https://doi.org/10.1111/j.1467-8624.1995.tb00952.x

Ministry of National Education. (2017). National Education Statistics (2016/'17). Retrieved October 10, 2017, from http://sgb.meb.gov.tr/meb_iys_dosyalar/2017_09/08151328_meb_ istatistikleri_orgun_egitim_2016_2017.pdf

Moon, S. M., \& Hall, A. S. (1998). Family therapy with intellectually and creatively gifted children. Journal of Marital and Family Therapy, 24, 59-80. https://doi.org/10.1111/j.17520606.1998.tb01063.x

Moon, S. M., \& Thomas, V. (2002). Family therapy with gifted and talented adolescents. Journal of Secondary Gifted Education, 14(2), 107-113. https://doi.org/10.4219/jsge2003-422

Morawska, A., \& Sanders, M. R. (2008). Parenting gifted and talented children: What are the key child behaviour and parenting issues? Australian and New Zealand Journal of Psychiatry, 42(9), 819-827. https://doi.org/10.1080/00048670802277271

Morawska, A., \& Sanders, M. R. (2009). Parenting gifted and talented children: Conceptual and empirical foundations. Gifted Child Quarterly, 53, 163-172. https://doi.org/10.1177/ 0016986209334962 
Ogurlu U. (2016). The effect of parent training program for parents of gifted children on parental self-efficacy and awareness. Millî Ĕ̈itim, 209, 145-159.

Ogurlu, U., \& Yaman, Y. (2013). Guidance needs of gifted and talented children's parents. Turkish Journal of Giftedness \& Education, 3(2), 81-94.

Pfeiffer, S. I. (2013). Serving the Gifted. Evidence-Based, Clinical and Psychoeducational Practice. New York: Routledge.

Reichenberg, A., \& Landau, E. (2009). Families of gifted children. In L. Shavinina (Ed.), International Handbook on Giftedness (pp. 873-883). Amsterdam: Springer Science. https://doi.org/10.1007/978-1-4020-6162-2_43

Renati, R., Bonfiglio, N. S., \& Pfeiffer, S. (2017). Challenges raising a gifted child: Stress and resilience factors within the family. Gifted Education International, 33(2), 145-162. https://doi.org/10.1177/0261429416650948

Robin, A. L., Koepke, T., \& Moye, A. (1990). Multidimensional assessment of parent-adolescent relations. A Journal of Consulting and Clinical Psychology, 2(4), 451-459. https://doi.org/10.1037/1040-3590.2.4.451

Roehling, P. V., \& Robin, A. L. (1986). Development and validation of family beliefs inventory. A measure of unrealistic beliefs among parent and adolescents. Journal of Consulting and Clinical Psychology, 54, 693-697. https://doi.org/10.1037/0022-006X.54.5.693

Ross, A. O. (1964). The exceptional child in the family. New York: Grune \& Stratton.

Rotigel, J. V. (2003). Understanding the young gifted child: Guidelines for parents, families, and educators. Early Childhood Education Journal, 30(4), 209-214. https://doi.org/10.1023/ A:1023331422963

Sameroff, A. J., \& Fiese, B. H. (2000). Transactional regulation: The developmental ecology of early intervention. In J. P. Shonkoff, \& S. J. Meisels (Eds.), Handbook of early childhood intervention (2nd ed., pp. 135-159). New York: Cambridge University Press. https://doi.org/ $10.1017 /$ CBO9780511529320.009

Schader, R. M. (2008). Parenting. In J. A. Plucker, \& C. M. Callahan (Eds.), Critical issues and practices in gifted education (pp. 479-492). Waco, TX: Prufrock Press.

Shore, B. M., Cornell, D. G., Robinson, A., \& Ward, V. S. (1991). Recommended practices in gifted education. New York: Teachers College Press.

Silverman, L. K. (1997). Family counseling with the gifted. In N. Colangelo, \& G. A. Davis (Eds.), Handbook of gifted education (pp. 382-397). Boston: Allyn and Bacon.

Silverman, L. K. (2013). Giftedness 101. Springer Publishing Company.

Silverman, L. K., \& Golon, A. (2008). Clinical practice with gifted families. In S. I. Pfeiffer (Ed.), Handbook of the gifted \& talented: A psychological approach. (pp. 199-222). New York: Springer. https://doi.org/10.1007/978-0-387-74401-8_11 


\section{Macrothink}

Solow, R. (2001). Parents' conceptions of giftedness. Gifted Child Today, 24(2), 14-22. https://doi.org/10.4219/gct-2001-533

Starko, T. J. (1991). Parent stress and parent irrational beliefs: Mmother-father differences (Unpublished Master's Thesis, University of Alberta, Edmonton).

Szentagotai, A., \& Jones, J. (2009). The behavioral consequences of irrational beliefs. In D. David, S. J. Lynn, \& A. Ellis (Eds.), Rational and irrational beliefs: Research, theory, and clinical practice (pp. 75-97). Oxford University Press. https://doi.org/10.1093/acprof:oso/ 9780195182231.003.0005

Webb, J. T., \& DeVries, A. R. (1998). Gifted parent groups: The SENG Model. Scottsdale, AZ: Gifted Psychology Press.

Weber, C. L., \& Stanley, L. (2012). Educating parents of gifted children: Designing effective workshops for changing parent perceptions. Gifted Child Today, 35(2), 128-136. https://doi.org/10.1177/1076217512437734

Weiner, B. (1995). Judgements of responsibility: A foundation for a theory of social conduct. New York: The Guilford Press.

Welsh, B. J. (2014). The relationship between identified gifted and talented children and their parents (Unpublished Doctoral Dissertation, St. John's Unıversity, School of Education and Human Services).

Winner, E. (2000). The origins and ends of giftedness. American Psychologist, 55, 159-169. https://doi.org/10.1037/0003-066X.55.1.159

\section{Copyright Disclaimer}

Copyright for this article is retained by the author(s), with first publication rights granted to the journal.

This is an open-access article distributed under the terms and conditions of the Creative Commons Attribution license (http://creativecommons.org/licenses/by/3.0/). 